\title{
Efficacy of Asparagus recemosus (Satavar) in stimulating follicular growth and ovulation in anovulatory infertility: a randomized controlled trial
}

\author{
Sana Fatima Majeedi*, Ismath Shameem, Mariyam Roqaiya
}

Department of Ilmul Qabalat wa Amraze Niswan, NIUM, Bangalore-91, Karnataka, India

Received: 30 October 2015

Revised: 17 December 2015

Accepted: 08 January 2016

\author{
*Correspondence: \\ Dr. Sana Fatima Majeedi, \\ E-mail: sfmajeedi@gmail.com
}

Copyright: (C) the author(s), publisher and licensee Medip Academy. This is an open-access article distributed under the terms of the Creative Commons Attribution Non-Commercial License, which permits unrestricted non-commercial use, distribution, and reproduction in any medium, provided the original work is properly cited.

\begin{abstract}
Background: Anovulation is the commonest cause of female infertility, responsible for $30 \%$ of cases and the most frequent cause of anovulation in women is polycystic ovarian syndrome. The aim of the study was to evaluate the anovulatory efficacy of Asparagus recemosus, commonly known as Satavar, in stimulating follicular growth and ovulation in an ovulatory infertility.

Methods: A randomized standard controlled study was carried out at the National institute of Unani medicine Hospital, Bangalore. Patients $(n=40)$ were randomly allocated to test $(n=20)$ and control $(n=20)$ groups. Infertile women in the age group of 18-40 years with menstrual irregularities, polycystic ovarian disease \& spouse normal seminogram were included in the study. Patients with primary ovarian failure, thyroid dysfunction, hyperprolactinaemia, systemic illnesses, malignancy and those on hormonal therapy in last 3 months were excluded. In test group, 6 grams of $A$. recemosus powder twice daily from day 1-14 of cycle and in control group, clomiphene citrate $50 \mathrm{mg}$ once daily from day 2-6 of cycle was administered orally for 2 consecutive cycles. Primary outcome measures (follicular growth \& ovulation) and secondary outcome measure (conception) were assessed for improvement. Data were analyzed using Student ' $t$ 'test, chi-square and Fisher exact test.

Results: After $1^{\text {st }}$ and $2^{\text {nd }}$ cycles of treatment, follicular growth was $30 \%$ and $40 \%$ in test group and $60 \% \& 50 \%$ in control group; ovulatory rate was $25 \% \& 30 \%$ in test group and $40 \% \& 25 \%$ in control group and conception rate was $0 \%$ in test group and $10 \%$ and $5 \%$ in control group.

Conclusions: The effect of test drug was comparable with that of control drug in stimulating follicular growth \& ovulation, though the drug was not as effective as control drug to achieve conception.
\end{abstract}

Keywords: Anovulatory infertility, Asparagus recemosus, Clomiphene citrate, Follicular growth, Ovulation, Conception

\section{INTRODUCTION}

Anovulation is the most common etiologic factor of infertility ${ }^{1,2}$ which accounts for approximately $30 \%$ of all cases of female infertility. ${ }^{3,4}$ The causes of anovulation include hypothalamic failure, hyperprolactinaemia, polycystic ovarian syndrome, premature ovarian failure, subclinical hypothyroidism, adrenal failure and obesity. Out of these disorders, polycystic ovarian syndrome is the commonest, easily diagnosed and most treatable cause of an anovulatory infertility ${ }^{5}$ accounting for $75 \%$ of cases. In classical Unani literature, the concept of ovulation is mentioned by renowned Unani physician Al Majoosi in his treatise Kamilus Sana centuries ago. He states that an ovary produces a follicle which secretes ovum, the later reaches the uterine cavity through the fallopian tubes. ${ }^{6}$ The description of anovulation is mentioned under the headings of infertility (uqr) which is 
defined as inability to conceive either due to defect in sperm of male partner or ovum of female partner or both. ${ }^{6-8}$ Chronic anovulation (Tooleehtebase mani) is mainly caused by altered temperament (sue mizaj) which may be either due to excess heat, cold, moist \& dryness. Any sort of defect in ovaries leads to faulty production of ovum, which is either due to oligo-ovulation/anovulation, dysovulation $^{9}$ or extreme cold. ${ }^{10}$ The only treatment available in conventional medicine for follicle growth and ovulation is hormone therapy, which though effective but has its own side effects. Hence, there is a need for alternative therapy which is to be safe, effective, easily available and free from side effects. Herbal drugs are safe with lesser side effects and presence of multiple active compounds in them provide a potentiating effect such as they enhance the immunity of the body, regularize the menstrual cycle and induce the ovulation by maintaining hormonal balance. ${ }^{11}$ In Unani system of medicine, principles of treatment includes correction of altered temperament (sue mizaj), maintaining body weight with regimen, diet and drugs; use of emmenagogue (mudir haiz) and ovulation inducing (Mwallide mani) drugs. ${ }^{6,7}$ Satavar was selected as research drug due to its ovulation inducing (Mwallide mani) and aphrodisiac (muqawwi bah) propereties, $^{12}$ and is known to contain phytohormones (steroidal saponins \& glycosides) which stimulates the follicular growth by maintaining the hormonal balance. ${ }^{13}$ The aim of the study was to evaluate the effectiveness of satavar scientifically in patients of anovulatory infertility.

\section{METHODS}

\section{Study design}

A single blind standard controlled randomized study was carried out from November 2013 and March 2015 in OBG Dept. National Institute of Unani Medicine Hospital, Bangalore. Ethical clearance was obtained from the institutional ethical committee.

\section{Participants}

Total 235 patients were evaluated for the study, 115 patients didn't meet the inclusion criteria and 80 denied participation, hence were excluded (Figure 1). Sample size of 40 was estimated on the basis of previous study conducted on induction of ovulation in anovulatory infertility $^{14}$ and were randomly allocated in two equal groups by computer generated simple randomization table. All participants gave written informed consent prior to study.

\section{Selection criteria}

Married women in the age group of 18-40 years who were anxious to conceive having irregular menstrual cycle, with features of polycystic ovarian disease and no follicular growth \& ovulation on TVS and spouse normal seminogram were included in the study. Patients with primary ovarian failure, thyroid dysfunction, hyperprolactinaemia, systemic illnesses, malignancy and on hormonal therapy for anovulation within last 3 months were excluded. Investigations like UPT, RBS, thyroid profile, Sr. prolactin and spouse semen analysis were done for exclusion.

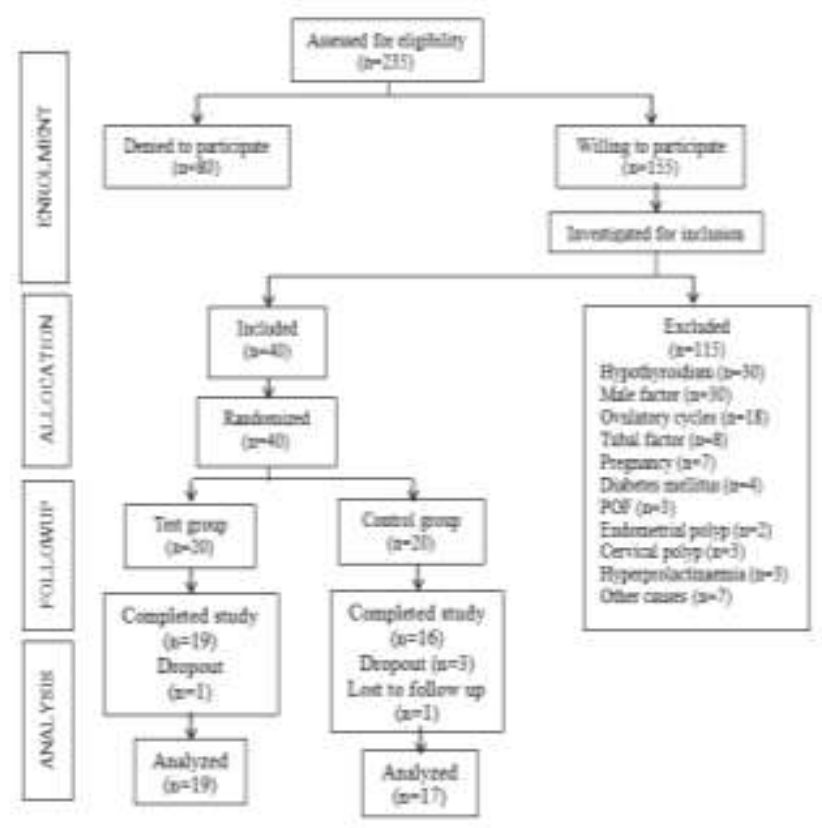

Figure 1: Consort flow chart.

\section{Procedure}

On entry into the study, detailed history were enquired from each patient regarding infertility, particularly about its duration, type, any pervious treatment received etc. Complete physical examination was performed in all patients and findings were recorded in the case record form designed for the study. In patients with oligomenorrhoea or amenorrhoea, emmenagogue drugs (safoof or hab mudir haiz with sharbat bazoori) were given for 1-2 weeks to induce menstruation. Once menstruation was established, patients were advised to report on $\mathrm{D}_{1}$ of menstrual cycle for routine investigations, lipid profile, LFT and RFT.

\section{Intervention}

In test group, 12 grams of satavar powder ${ }^{15,16}$ was administered orally, with milk in two divided doses daily from $\mathrm{D}_{1-14}$ of cycle and in control group, clomiphene citrate $50 \mathrm{mg}$ once daily ${ }^{17-19}$ was administered orally from $\mathrm{D}_{2-6}$ of cycle for two consecutive cycles. Patients of both groups were unaware of treatment provided as medicine was dispensed to one patient at a time. Compliance was assessed at every follow up visit by examining the packets in which medicine was dispensed. 


\section{Follow up}

Patients were followed on $1^{\text {st }}$ day of every cycle to start the therapy and were instructed to come for follicular study from $\mathrm{D}_{12}-\mathrm{D}_{16}$ on every alternate day and again on $\mathrm{D}_{21}$ of cycle for serum progesterone. Timed intercourse was advised to the patients at the time of ovulation. If the patient had missed period, then urine for pregnancy test was done to detect the pregnancy. If UPT was negative, no medicine was prescribed for withdrawal bleeding; rather, the patient was asked to wait for spontaneous menstruation and simultaneously pattern of menstrual cycle were also noted. Patients were also enquired for any adverse effect of test drug during the trial. After treatment, patients were followed once in a month for one month to look for spontaneous follicular growth and ovulation on TVS.

\section{Subjective parameter}

Menstrual irregularity was assessed by menstrual cycle pattern which includes nature of cycle, duration of cycle, duration of flow and amount of flow.

\section{Objective parameters}

TVS for follicular study was performed to detect ovulation (follicular growth \& rupture, endometrial thickness, presence of fluid in POD) and Serum progesterone was done to confirm ovulation.

\section{Outcome measures}

Primary outcome measures were follicular growth \& ovulation. Follicular growth was confirmed by the presence of total no. of growing follicles on TVS, no. of follicle $>10 \mathrm{~mm}$, no. of follicle $>14 \mathrm{~mm}$, no. of follicle $>17 \mathrm{~mm} .{ }^{20}$ Secondary outcome measure was conception which was confirmed either by UPT or ultrasonography.

\section{Statistical analysis}

The Statistical software namely SAS 9.2, SPSS 15.0, Stata 10.1, Med Calc 9.0.1, Systat 12.0 and $R$ environment ver.2.11.1 were used to analyze the data and Microsoft word and Excel have been used to generate graphs and tables. Significance was assessed at $5 \%$ level. Student t test, chi-square/Fisher exact test were used to analyze the data.

\section{RESULTS}

\section{Baseline characteristics}

Mean age of patients in test \& control group were $22.85 \pm 2.35$ and $24.85 \pm 4.11$ respectively ( $\mathrm{p}=0.102)$. Majority of patients $26(65 \%)$ had primary infertility, mean \pm SD of duration of infertility were $3.40 \pm 2.36 \&$ $3.83 \pm 2.72$ respectively in test and control group. Maximum patients $22(55 \%)$ were from upper lower class; and majority of the patients 31 (77.5\%) had predominance of balghami mizaj (Table 1).

Table 1: Comparison of baseline characteristics in two groups.

\begin{tabular}{|llll|}
\hline $\begin{array}{l}\text { Baseline } \\
\text { characteristics }\end{array}$ & $\begin{array}{l}\text { Test } \\
\text { Group } \\
(\mathrm{n}=20)\end{array}$ & $\begin{array}{l}\text { Control } \\
\text { Group } \\
(\mathrm{n}=20)\end{array}$ & $\begin{array}{l}\mathrm{p} \\
\text { value }\end{array}$ \\
\hline Age (years) & $22.85 \pm 2.35$ & $24.85 \pm 4.11$ & 0.102 \\
\hline Age at marriage & $18.55 \pm 2.56$ & $20.10 \pm 3.23$ & 0.101 \\
\hline Married life & $4.43 \pm 3.02$ & $4.78 \pm 2.98$ & 0.714 \\
\hline $\begin{array}{l}\text { Type of } \\
\text { infertility }\end{array}$ & $14(70.0 \%)$ & $12(60.0 \%)$ & 0.507 \\
$\begin{array}{l}\text { Primary } \\
\text { Secondary }\end{array}$ & $6(30.0 \%)$ & $8(40.0 \%)$ & \\
\hline $\begin{array}{l}\text { Duration of } \\
\text { infertility }\end{array}$ & $3.40 \pm 2.36$ & $3.83 \pm 2.72$ & 0.601 \\
\hline $\begin{array}{l}\text { Socioeconomic } \\
\text { status }\end{array}$ & & & \\
$\begin{array}{l}\text { Lower middle } \\
\text { Upper lower }\end{array}$ & $8(40.0 \%)$ & $6(30.0 \%)$ & 1.000 \\
Upper Middle & $2(10.0 \%)$ & $2(10.0 \%)$ & \\
\hline $\begin{array}{l}\text { Mizaj } \\
\text { Balghami }\end{array}$ & $16(80.0 \%)$ & $15(75.0 \%)$ & 1.000 \\
$\begin{array}{l}\text { Damvi } \\
\text { Safravi }\end{array}$ & $3(15.0 \%)$ & $3(15.0 \%)$ & \\
\hline
\end{tabular}

\section{Subjective parameters}

In test group, $75 \%$ patients had irregular cycle at base line which becomes regular in $65 \%$ after $1^{\text {st }}$ cycle, $73.7 \%$ after $2^{\text {nd }}$ cycle and $63.2 \%$ patients on post treatment follow up with a $\%$ change of 38.2 ; while in control group, $70 \%$ patients had irregular cycle at base line which becomes regular in $45 \%$ after $1^{\text {st }}$ cycle, $73.3 \%$ after $2^{\text {nd }}$ cycle and $76.9 \%$ patients on post treatment follow up with a $\%$ change of 46.9 (Table 2).

The mean \pm SD duration of cycle before treatment, after $1^{\text {st }} \& 2^{\text {nd }}$ cycle of treatment and on post treatment follow up were $70.40 \pm 32.28, \quad 38.35 \pm 13.52, \quad 35.11 \pm 18.01$, $38.58 \pm 21.87$ respectively in test group and $57.90 \pm 26.41$, $46.50 \pm 20.83,36.50 \pm 17.38,40.77 \pm 28.91$ respectively in control group. The difference was strongly significant $(\mathrm{p}<0.001)$ in test group as compare to control group (Table 3).

\section{Objective parameters}

After $1^{\text {st }} \& 2^{\text {nd }}$ cycle of treatment number of follicle $>10$ $\mathrm{mm}$ were $0.20 \pm 0.41,0.32 \pm 0.48$ respectively in test group and $1.05 \pm 1.28,1.20 \pm 1.21$ respectively in control group. The difference in follicle growth was strongly significant in control group (inter group comparison) ( $\mathrm{p}=0.007 \&$ 0.006). The difference in follicle growth was suggestive significant after $1^{\text {st }}$ cycle of treatment $(\mathrm{p}=0.095)$ and even on post treatment follow up $(\mathrm{p}=0.082)$ in control group (intra group comparison). Number of follicle $>14 \mathrm{~mm}$ after $1^{\text {st }} \& 2^{\text {nd }}$ cycle of treatment were $0.26 \pm 0.45$, 
$0.29 \pm 0.47$, respectively in test group and $0.75 \pm 1.13$, $0.85 \pm 0.99$ respectively in control group. The difference in follicle growth was suggestively significant in control group (inter group comparison) $(\mathrm{p}=0.093 \& 0.052)$. The difference in follicle growth was suggestive significant in test group $(\mathrm{p}=0.083)$ after $1^{\text {st }}$ cycle of treatment and even in control group $(\mathrm{p}=0.017)$ on post treatment follow up (intra group comparison). Number of follicle $>17 \mathrm{~mm}$ after $1^{\text {st }} \& 2^{\text {nd }}$ cycle of treatment were $0.00 \pm 0.00$, $0.08 \pm 0.28$, respectively in test group and $0.53 \pm 0.99$, $0.50 \pm 0.85$ respectively in control group. The difference in follicle growth was moderately significant $(p=0.046)$ in control group after $1^{\text {st }}$ cycle of treatment (inter group comparison) and suggestive significant $(\mathrm{p}=0.056)$ in test group on post treatment follow up (intra group comparison) (Table 4).

Table 2: Comparison of nature of menstrual cycle in two groups.

\begin{tabular}{|llllll|}
\hline $\begin{array}{l}\text { Nature of menstrual } \\
\text { cycle }\end{array}$ & $\begin{array}{l}\text { Before } \\
\text { treatment }\end{array}$ & $\begin{array}{l}\text { After I } \\
\text { cycle treatment }\end{array}$ & $\begin{array}{l}\text { After II } \\
\text { cycle treatment }\end{array}$ & $\begin{array}{l}\text { Follow up after } \\
\text { treatment }\end{array}$ & \% change \\
$\begin{array}{l}\text { Trregular } \\
\text { Regular }\end{array}$ & $15(75 \%)$ & $7(35 \%)$ & $5(26.3 \%)$ & $7(36.8 \%)$ & $-38.2 \%$ \\
\hline $\begin{array}{l}\text { Control group } \\
\text { Irregular }\end{array}$ & $5(25 \%)$ & $13(65 \%)$ & $14(73.7 \%)$ & $12(63.2 \%)$ & $38.2 \%$ \\
Regular & $14(70 \%)$ & $11(55 \%)$ & $4(26.7 \%)$ & $3(23.1 \%)$ & $-46.9 \%$ \\
\hline p value & $6(30 \%)$ & $9(45 \%)$ & $11(73.3 \%)$ & $10(76.9 \%)$ & $46.9 \%$ \\
\hline
\end{tabular}

Table 3: Comparison of menstrual cycle pattern in two groups.

\begin{tabular}{|lllll|}
\hline Duration of cycle (Days) & $\begin{array}{l}\text { Before } \\
\text { treatment }\end{array}$ & $\begin{array}{l}\text { After I } \\
\text { cycle treatment }\end{array}$ & $\begin{array}{l}\text { After II } \\
\text { cycle treatment }\end{array}$ & $\begin{array}{l}\text { Follow up after } \\
\text { treatment }\end{array}$ \\
\hline Test group & $70.40 \pm 32.28$ & $\begin{array}{l}38.35 \pm 13.52 \\
(\mathrm{p}<0.001 * *)\end{array}$ & $\begin{array}{l}35.11 \pm 18.01 \\
(\mathrm{p}<0.001 * *)\end{array}$ & $\begin{array}{l}38.58 \pm 21.87 \\
(\mathrm{p}=0.001 * *)\end{array}$ \\
\hline Control group & $57.90 \pm 26.41$ & $\begin{array}{l}46.50 \pm 20.83 \\
(\mathrm{p}=0.083+)\end{array}$ & $\begin{array}{l}36.50 \pm 17.38 \\
\left(\mathrm{p}=0.033^{*}\right)\end{array}$ & $\begin{array}{l}40.77 \pm 28.91 \\
(\mathrm{p}=0.173)\end{array}$ \\
\hline $\mathrm{p}$ value & 0.150 & 0.818 & 0.809 \\
\hline Duration of flow (Days) & 0.188 & & & \\
\hline Test group & $4.90 \pm 3.11$ & $5.05 \pm 2.98$ & $4.68 \pm 1.95$ & $4.68 \pm 1.95$ \\
\hline Control group & $4.45 \pm 2.35$ & $4.35 \pm 2.25$ & $4.44 \pm 2.22$ & $4.36 \pm 2.50$ \\
\hline p value & 0.609 & 0.408 & 0.728 & 0.675 \\
\hline Amount of flow (Pads/cycle) & & & & $8.61 \pm 4.39$ \\
\hline Test group & $9.26 \pm 6.60$ & $9.30 \pm 6.63$ & $7.13 \pm 4.39$ & $7.46 \pm 5.03$ \\
\hline Control group & $7.15 \pm 5.06$ & $6.85 \pm 5.17$ & 0.355 & 0.504 \\
\hline p value & 0.268 & 0.200 & & \\
\hline
\end{tabular}

Table 4: Comparison of follicle growth on TVS in two groups.

\begin{tabular}{|c|c|c|c|c|}
\hline Follicle growth & $\begin{array}{l}\text { Before } \\
\text { treatment }\end{array}$ & $\begin{array}{l}\text { After I } \\
\text { cycle treatment }\end{array}$ & $\begin{array}{l}\text { After II } \\
\text { cycle treatment }\end{array}$ & $\begin{array}{l}\text { Follow up after } \\
\text { treatment }\end{array}$ \\
\hline \multicolumn{5}{|c|}{ No. of follicle $>10 \mathrm{~mm}$} \\
\hline Test group & $0.50 \pm 1.00$ & $0.20 \pm 0.41$ & $0.32 \pm 0.48$ & $0.21 \pm 0.54$ \\
\hline Control group & $0.60 \pm 0.60$ & $1.05 \pm 1.28$ & $1.20 \pm 1.21$ & $0.15 \pm 0.38$ \\
\hline $\mathrm{p}$ value & 0.703 & $0.007 * *$ & $0.006^{* *}$ & 0.744 \\
\hline \multicolumn{5}{|c|}{ No. of Follicle $>14 \mathrm{~mm}$} \\
\hline Test group & $0.35 \pm 0.67$ & $0.26 \pm 0.45(\mathrm{p}=0.429)$ & $0.29 \pm 0.47(\mathrm{p}=0.431)$ & $0.05 \pm 0.23(\mathrm{p}=0.083+)$ \\
\hline Control group & $0.30 \pm 0.47$ & $0.75 \pm 1.13(\mathrm{p}=0.088+)$ & $0.85 \pm 0.99(\mathrm{p}=0.111)$ & $0.00 \pm 0.00(\mathrm{p}=0.017 *)$ \\
\hline $\mathrm{p}$ value & 0.786 & $0.093+$ & $0.052+$ & 0.436 \\
\hline \multicolumn{5}{|c|}{ No. of Follicle $>17 \mathrm{~mm}$} \\
\hline Test group & $0.25 \pm 0.55$ & $0.00 \pm 0.00(\mathrm{p}=0.164)$ & $0.08 \pm 0.28(\mathrm{p}=0.337)$ & $0.00 \pm 0.00(\mathrm{p}=0.056+)$ \\
\hline Control group & $0.20 \pm 0.41$ & $0.53 \pm 0.99(\mathrm{p}=0.136)$ & $0.50 \pm 0.85(\mathrm{p}=0.193)$ & $0.00 \pm 0.00(\mathrm{p}=0.167)$ \\
\hline $\mathrm{p}$ value & 0.746 & $0.046^{*}$ & 0.105 & - \\
\hline
\end{tabular}


After $1^{\text {st }} \& 2^{\text {nd }}$ cycle of treatment, $25 \%$ and $21 \%$ patients had fluid in POD in test group with a percentage change of $5.3 \%$, while in control group it was $20 \% \& 40 \%$ and the difference $(\mathrm{p}=1)$; ovulation was detected in $25 \%$ and $31.6 \%$ patients in test group and $20 \%$ and $0 \%$ patients in control group; serum progesterone was $1.43 \pm 3.46 \&$ $3.12 \pm 5.83$ respectively in test group and 4.51 \pm 7.53 , $4.15 \pm 7.38$ respectively in control group $(\mathrm{p}>0.05)$ (Table $5)$.

\section{Primary outcome measures}

After $1^{\text {st }} \& 2^{\text {nd }}$ cycles of treatment, follicular growth was $30 \% \& 40 \%$ in test group and $60 \%$ \& $50 \%$ in control group. The difference was suggestive significant $(\mathrm{p}=0.057)$ in control group after $1^{\text {st }}$ cycle of treatment although the difference was not significant after $2^{\text {nd }}$ cycle of treatment $(\mathrm{p}>0.05)$. After $1^{\text {st }} \& 2^{\text {nd }}$ cycles of treatment, ovulatory rate was $25 \% \& 30 \%$ in test group and $40 \%$ \& $25 \%$ in control group and the difference was not significant statistically $(\mathrm{p}>0.05)$.

\section{Secondary outcome measure}

After $1^{\text {st }} \& 2^{\text {nd }}$ cycles of treatment, conception rate was $0 \%$ in test group and $10 \% \& 5 \%$ in control group (Table $6)$.

Table 5: Comparison of fluid in POD \& ovulation on TVS; Serum progesterone in two groups.

\begin{tabular}{|c|c|c|c|c|c|}
\hline Fluid in POD & Before treatment & $\begin{array}{l}\text { After I cycle } \\
\text { treatment }\end{array}$ & $\begin{array}{l}\text { After II cycle } \\
\text { treatment }\end{array}$ & $\begin{array}{l}\text { Follow up after } \\
\text { treatment }\end{array}$ & $\%$ change \\
\hline Test group & & & & & \\
\hline No & $20(100 \%)$ & $15(75 \%)$ & $15(78.9 \%)$ & $18(94.7 \%)$ & $-5.3 \%$ \\
\hline Yes & $0(0 \%)$ & $5(25 \%)$ & $4(21.1 \%)$ & $1(5.3 \%)$ & $5.3 \%$ \\
\hline Control group & & & & & \\
\hline No & $20(100 \%)$ & $16(80 \%)$ & $9(60 \%)$ & $13(100 \%)$ & $0.0 \%$ \\
\hline Yes & $0(0 \%)$ & $4(20 \%)$ & $6(40 \%)$ & $0(0 \%)$ & $0.0 \%$ \\
\hline p value & 1.000 & 1.000 & 0.465 & 1.000 & - \\
\hline Ovulation & & & & & \\
\hline Test group & & & & & \\
\hline No & $20(100 \%)$ & $15(75 \%)$ & $13(68.4 \%)$ & $18(94.7 \%)$ & $-5.3 \%$ \\
\hline Yes & $0(0 \%)$ & $5(25 \%)$ & $6(31.6 \%)$ & $1(5.3 \%)$ & $5.3 \%$ \\
\hline Control group & & & & & \\
\hline No & $20(100 \%)$ & $16(80 \%)$ & $15(60 \%)$ & $13(100 \%)$ & $0.0 \%$ \\
\hline Yes & $0(0 \%)$ & $4(20 \%)$ & $0(0 \%)$ & $0(0 \%)$ & $0.0 \%$ \\
\hline p value & 1.000 & 1.000 & 0.723 & 1.000 & - \\
\hline Serum progesterone & After I Cycle & reatment & Cycle Treatment & p val & \\
\hline Test group & $1.43 \pm 3.46$ & & & 0.113 & \\
\hline Control group & $4.51 \pm 7.53$ & & & 0.657 & \\
\hline
\end{tabular}

Table 6: Comparison of outcome measures in two groups.

\begin{tabular}{|llll|}
\hline Outcome Measures & $\begin{array}{l}\text { Test group } \\
(\mathbf{n}=20)\end{array}$ & $\begin{array}{l}\text { Control group } \\
(\mathbf{n = 2 0})\end{array}$ & p value \\
\hline Follicular growth & $2(10.0 \%)$ & $2(10.0 \%)$ & 1.000 \\
\hline Before treatment & $6(30.0 \%)$ & $12(60.0 \%)$ & $0.057+$ \\
\hline After I cycle treatment & $8(40.0 \%)$ & $10(50.0 \%)$ & 0.525 \\
\hline After II cycle treatment & $3(15.0 \%)$ & $2(10.0 \%)$ & 0.633 \\
\hline Follow up after treatment & & & - \\
\hline Ovulation & $0(0.0 \%)$ & $0(0.0 \%)$ & 0.311 \\
\hline Before treatment & $5(25.0 \%)$ & $8(40.0 \%)$ & 0.723 \\
\hline After I cycle treatment & $6(30.0 \%)$ & $5(25.0 \%)$ & 1.000 \\
\hline After II cycle treatment & $1(5.0 \%)$ & $2(10.0 \%)$ & 1.000 \\
\hline Follow up after treatment & & & 0.487 \\
\hline Conception & $0(0.0 \%)$ & $0(0.0 \%)$ & 1.000 \\
\hline Before treatment & $0(0.0 \%)$ & $2(10.0 \%)$ & 1.000 \\
\hline After I cycle treatment & $0(0.0 \%)$ & $1(5.0 \%)$ & $0(0.0)$ \\
\hline After II cycle treatment & $0(0.0 \%)$ & & \\
\hline Follow up after treatment & & \\
\hline
\end{tabular}




\section{DISCUSSION}

Baseline characteristics were statistically similar in both groups $(\mathrm{p}>0.05)$. Mean age of patients were 22.85 \pm 2.35 and $24.85 \pm 4.11$ respectively in test \& control group; majority of the patients were belonged to upper lower SES, had primary infertility within 1-5 years of duration, possessed balghami mizaj and had PCOD on ultrasonography (Table 1).

\section{Subjective parameters}

In test group, $63.2 \%$ patients achieved regular menstrual cycles and $36.8 \%$ had persistent irregular cycles with a $\%$ change of $38.2 \%$; while in control group, $76.9 \%$ patients achieved regular menstrual cycles and $23.1 \%$ had persistent irregular cycles with a $\%$ change of $46.9 \%$ after treatment. Qayyum B et $\mathrm{al}^{21}$ reported $73 \%$ patients achieved regular menstrual cycles and $26 \%$ had persistent irregular cycles after treatment which is in accordance with the present study (Table 2). Strongly significant reduction in duration of cycle $(\mathrm{p}<0.001)$, was observed after every cycle of treatment in test group as compared to control group on intra group comparison, although the difference was not significant on inter group comparison. No significant difference in amount of flow \& duration of flow was observed in both groups (Table 3 ).

\section{Objective parameters}

After $1^{\text {st }} \& 2^{\text {nd }}$ cycle of treatment, strongly significant difference in follicle growth $(>10 \mathrm{~mm})$ was observed in control group $(\mathrm{p}=0.007 \& 0.006)$; the difference in follicle growth $(>14 \mathrm{~mm})$ was suggestively significant $(\mathrm{p}=0.093 \& 0.052)$ in control group and the difference in follicle growth $(>17 \mathrm{~mm})$ was moderately significant $(p=0.046)$ in control group after $1^{\text {st }}$ cycle of treatment on inter group comparison (Table 4). Ovulation was detected in $25 \%$ and $31.6 \%$ patients in test group and $20 \%$ and $0 \%$ patients in control group. No significant differences in endometrial thickness, fluid in POD \& Sr. progesterone were observed between two groups with $\mathrm{p}>0.05$ (Table $5)$.

\section{Outcome measures}

After $1^{\text {st }}$ and $2^{\text {nd }}$ cycles of treatment, follicular growth was $30 \% \& 40 \%$ in test group and $60 \% \& 50 \%$ in control group; ovulatory rate was $25 \% \& 30 \%$ in test group and $40 \% \& 25 \%$ in control group. Kafeel $\mathrm{G}$ et $\mathrm{al}^{22}$ reported ovulatory rate of $40 \%, \& 35.3 \%$ which is in conformance with the present study. Conception rate was $0 \%$ in test group and $10 \%$ \& $5 \%$ in control group. Kafeel $\mathrm{G}$ et $\mathrm{al}^{22}$ reported conception rate of $10 \%, \& 18.8 \%$ on $1^{\text {st }}$ and $3^{\text {rd }}$ cycles of treatment respectively; which was not in accordance with the present study. Test drug was well tolerated with no adverse effect reported as safety profile was within normal limits. Limitations of study were small sample size, use of single drug for short duration of intervention, loss of long term follow up for efficacy and serial follicular monitoring was not performed by the same observer. Further trials with variable dose regimen with long term follow up are required to confirm the efficacy of test drug; moreover, compound formulation could be preferable than single drugs for ovulation induction (Table 6).

\section{CONCLUSIONS}

Satavar was effective in stimulating follicular growth and ovulation, as it possesses the properties like ovulation inducing (mwallide mani) and aphrodisiac (muqawwi bah), and is known to contain phytohormones (steroidal saponins \& glycosides). The effect of test drug was comparable with that of control drug in stimulating follicular growth \& ovulation, though the drug was not effective to achieve conception.

\section{ACKNOWLEDGEMENTS}

Authors are grateful to the Director, National Institute of Unani Medicine, Bangalore for providing all facilities to carry out the research work. Authors are thankful to Dr. K.P. Suresh Biostatistician and Scientist, National Institute of veterinary epidemiology disease informatics (NIVEDI), Bangalore; to carry out statistical work.

\section{Funding: National Institute of Unani Medicine, Bangalore \\ Conflict of interest: None declared \\ Ethical approval: The study was approved by the Institutional Ethics Committee}

\section{REFERENCES}

1. Branigan FE, Estes MA. A randomized clinical trial of treatment of clomiphene citrate-resistant anovulation with the use of oral contraceptive pill suppression and repeat clomiphene citrate treatment. Am J Obstet Gynecol. 2003;188(6):1424-30.

2. Legro RS, Brzyski RG, Diamond MP, Coutifaris C, Schlaff WD, Casson $\mathrm{P}$ et al. Letrozole versus clomiphene for Infertility in polycystic ovary syndrome. N Engl J Med. 2014;371:119-29.

3. Berek JS, Adashi EY, Hillared PA. Novak's Gynaecology. $12^{\text {th }}$ ed. London: Williams and Wilkins;1996:149-68,837-40,915-25,935-41.

4. Serour GI, Aboulghar M, Al Bahar A, Hugues JN, Esmat K. Phase IV open-label randomized study of low-dose recombinant human follicle-stimulating hormone protocol for ovulation induction. Reproductive Biology and Endocrinology. 2014;12(52):1-9.

5. Kumar P, Malhotra N. Jefffcoate's Principles of Gynaecolgy. $7^{\text {th }}$ ed. New Delhi: Jaypee Brothers Medical Publishers (P) Ltd;2008:56-87,101-10,38596,699-721.

6. Majoosi ABA. Kamilus Sana (Urdu trans. by Kantoori GH) Vol I \& II. New Delhi: Idarae-KitabulShifa;2010:538-40,498-99. 
7. Ibn Sina. Al Qanoon Fil Tib (Urdu trans. by Kantoori GH). New Delhi: Idarae-Kitabul-Shifa;2010:106570, 1445-47.

8. Jurjani AH. Zakheerae Khawarzam Shahi (Urdu trans. by Khan AH). Vol. VI \& VIII. New Delhi: Idarae-Kitabul-Shifa; 2010:27-8,606-09.

9. Khan A. Al Akseer (Urdu trans. by Kabeeruddin). New Delhi: Idarae-Kitabul-Shifa; 2011:819-21.

10. Razi ABZ. Al HawiFilTib. Vol IX. New Delhi: CCRUM;2001:77-86,90-1,99-100,102-3,106-8,1101,115-6.

11. Nagarathna PKM, Rajan PR, Raju Koneri R. A detailed study on polycystic ovarian syndrome and it's treatment with natural products. Intern J Toxicol Pharmacol Res. 2013-14;5(4):109-20.

12. Ghani NH. Khazayanul Advia. New Delhi: IdaraeKitabul-Shifa;2010:788-9.

13. Sharma K, Bhatnagar M. A. racemosus (Shatavari): a versatile female tonic. Intern $\mathrm{J}$ Pharm Biol Arch. 2011;2(3):855-63.

14. Parihar M, Gada D, Paul PG, Bhowmic S. Letrozole versus clomiphene citrate in Patients with anovulatory infertility. South Asian federation of obstetrics and gynecology. 2009;1(1):19-23.

15. Ghani NH. Khazayanul Advia. New Delhi: IdaraeKitabul-Shifa;2010:788-9.

16. Kabeeruddin M. Makhzanul Mufradat. New Delhi: Idarae-Kitabul-Shifa;2007:250.

17. Arulkumaran S, Sivanesaratnam V, Chatterjee A, Kumar P. Essentials of Gynaecology. $1^{\text {st }}$ ed. New Delhi: Jaypee Brothers Medical Publishers (P) Ltd; 2005:12-8,205-16,227,231-6.
18. Berek JS, Adashi EY, Hillared PA. Novak's Gynaecology. $12^{\text {th }}$ ed. London: Williams and Wilkins;1996:149-68,837-40,915-25,935-41.

19. Mukherjee GG, Chakravarty S, Pal B, Mukherjee B. Current obstetrics and gynecology. $1^{\text {st }}$ ed. New Delhi: Jaypee Brother's Medical Publishers (P) Ltd; 2007:232-8.

20. Balasch J, Fabregues F, Creus M, Puerto B, Penarrubia J, Vanrell JA. Follicular Development and hormone concentrations following recombinant fsh administration for anovulation associated with polycystic ovarian syndrome: Prospective randomized comparison between low-dose step-up and modified step-down regimens. Human Reproduction. 2001;16(4):652-6.

21. Qayyum B, Chaudhry SM, Sadaf J. Management of anovulatory infertility (polycystic ovary syndrome) with clomiphene alone and in combination with metformin. J Surg Pakistan (International). 2010;15(3):135-8.

22. Kafeel G, Shameem I, Begum W. Clinical evaluation of Unani formulation in ovulation induction in anovulatory infertility. J AYUSH: Ayurveda, Yoga, Unani, Siddha and Homeopathy. 2013;2(1):25-32.

Cite this article as: Majeedi SF, Shameem I, Roqaiya M. Efficacy of Asparagus recemosus (Satavar) in stimulating follicular growth and ovulation in anovulatory Infertility: a randomized controlled trial. Int J Reprod Contracept Obstet Gynecol 2016;5:310-6. 